\title{
Gaining Employee Commitment: Linking to Organizational Effectiveness
}

\author{
Mrs Amena Shahid \\ Lecturer, College of Business Administration \\ Associate Director, Teaching \& Learning Center, Prince Sultan University \\ P.O Box 53073 Riyadh 11583, Kingdom of Saudi Arabia \\ Tel: 96-654-599-8831Ｅ-mail: amena.shahid@gmail.com
}

\begin{abstract}
Dr Shahid. M. Azhar
Deputy Director of Development and Marketing for Center of Excellence Research in Engineering Materials (CEREM)

Center of Excellence Research in Engineering Materials (CEREM)

King Saud University, P.O. Box. 800 Riyadh 11421, Saudi Arabia

Tel: 96-61-469-5441_E-mail: sazhar@ksu.edu.sa

Received: August 30, 2012

doi:10.5296/jmr.v5i1.2319

Accepted: November 7, 2012 Published: January 1, 2013

URL: http://dx.doi.org/10.5296/jmr.v5i1.2319
\end{abstract}

\begin{abstract}
Employee commitment has been an important factor to determine the success of an organization. Employee commitment to an organization has acquired increasing demand as it aids the organizations to retain more staff and thereby increase in achievement, productivity and effectiveness. No organization in the current ambitious world can execute at peak levels unless each employee is committed to the organization's objectives and performs as an effective team member. The employment of good employees is thus demanding but of even extensive significance is the organizations ability to create a committed workforce. The aim of the study is to determine when employees who are engaged in their work \& committed to their organizations give their companies crucial competitive advantages - including elevated productivity and lower employee turnover and employee engagement is enduring predictor of concrete organizational performance clearly showing the two-way relationship between
\end{abstract}




\section{Macrothink}

Journal of Management Research ISSN 1941-899X 2013, Vol. 5, No. 1

employer and employee compared to the three constructs: job satisfaction, employee commitment and employee engagement.

Keywords: Motivation, Employee turnover, Teamwork, Job satisfaction, Employee engagement 


\section{Introduction}

Distinguished performing companies perceive that employee commitment is a premier contributing factor toward maintaining continual success and composing value. An engaged employee is participative and energized about their work and performs in an aspect that will progress the organization's interest. An engaged workforce helps optimize and retain talent for the long-term because the employees choose to continue, even when other employment opportunities prevail. The top three drivers of employee commitment are Fulfillment, Fairness, and Care \& Concern for employees. Put simply, committed employees want to enjoy their work, feel they are acknowledged, and know they are making a contribution to their company's imperative objectives. Additionally, employees who have trust in their leadership, and are trusted by their leadership, have a greater dedication and are ultimately more productive on the job. From last span of twentieth century onwards, theory like employee commitment and employee engagement started to emerge that competency and output lie within the employees' ability and commitment. Employers now envision that by focusing on employee engagement, they can create more efficient and productive workforce. Any drive of enhancement which is taken by management cannot be conducive without persistent involvement and engagement of employees. According to Katz (1964) employee behavior essential for organizational effectiveness includes employees (1) entering and remaining with the organization (2) carrying out specific role requirements and (3) engaging in innovative and spontaneous activity that goes beyond role prescriptions. Prevailing research concerning employee commitment features the hazard of viewing commitment as a shallow construct that can be enhanced by a particular human resource policy. This accepts that a particular practice, for example offering elastic working arrangements or more training, will have a significant and valuable effect on employee commitment. Unfortunately, in practice it is not that simple because there is no single solution. All employees' wants and needs cannot be addressed by a single policy. What is now credible is that, as long as the organization has been able to attract the right human capital and has provided an acceptable work environment, employee commitment will be considerably affected by the interactions that occur between colleagues and with their immediate and senior managers. Commitment is complex and continuous, and requires employers to discover ways of enhancing the work life of their employees. This article limits itself to discuss only the basic concepts on employee commitment based on recent literatures. It has four major parts. Firstly, the article examines the progress of the concept and its definition. Secondly, the article discusses the factors or drivers leading to employee commitment and engagement. Thirdly it details the impact of employee commitment and engagement on organizational performance indicators or business outcomes such as profitability, customer satisfaction, company growth, productivity and others pointing out its benefits and importance to organizations. Finally, the article suggests propositions the companies should take up to keep employees committed and engaged in their jobs.

\section{Literature Review}

Commitment manifests itself in apparent behavior. For example, people devote time and energy to fulfill their on-the-job responsibilities as well as their family, personal, community 
and spiritual obligations. In the past years commitment has been defined in many variant ways. Following set of definitions are procured from the literature.

- A stabilizing force that acts to maintain behavioral direction when expectancy/equity conditions are not met and do not function Scholl (1981).

- An obliging force which requires that the person honor the commitment, even in the face of fluctuating attitudes and whims Brown (1996).

- The psychological attachment felt by the person for the organization; it will reflect the degree to which the individual internalizes or adopts characteristics or perspectives of the organization (O’Reilly and Chatman ,1986).

- (Porter et al. and Schultz, 1974) discuss three major components of organizational commitment as being "a strong belief in and acceptance of the organization's goals, a willingness to exert considerable effort on behalf of the organization, and a definite desire to maintain organizational membership”.

\subsection{Benefits of a Committed Workforce}

Motivated, committed and proficient people are extensively valuable because they can often make things work despite less than perfect systems. The answer to higher productivity in an organization lies in a larger investment in creating committed people. Employee commitment should be viewed as a business prerequisite. Organizations that have difficulty in retaining and replacing competent employees will find it hard to optimize performance. Therefore the performance benefits grow from increased employee commitment and some of them listed as follows.

- Increased job satisfaction (Vandenberg and Lance, 1992).

- Decreased intention to leave (Balfour and Wechsler, 1996).

- Increased job performance (Mathieu and Zajac, 1990).

- Increased sales Barber et al( 1999).

- Decreased employee turnover Cohen (1991).

- Decreased absenteeism Cohen (1993) Barber et al (1999).

Employee engagement is essential to succeed in business, yet few organizations successfully define, measure or manage this leadership model. (Perrin's Global Workforce Study, 2003) uses the definition "employees' willingness and ability to help their company succeed, largely by providing discretionary effort on a sustainable basis.” According to the study, engagement is affected by many factors which involve both emotional and rational factors relating to work and the overall work experience. These experiences or "drivers" regulate engagement level. By managing these drivers to be positive experiences, leaders can motivate an innate desire for employees to consistently do their outstanding work. Employee engagement management is an alternative to commanding and controlling what specific work should be done, when, at what speed and with what kind of attitude. 


\section{Macrothink

Gallup organization defines employee engagement as the involvement with and enthusiasm for work. Gallup as cited by Dernovsek (2008) likens employee engagement to a positive employees' emotional attachment and employees' commitment. Robinson et al. (2004) define employee engagement as "a positive attitude held by the employee towards the organization and its value. An engaged employee is aware of business context, and works with colleagues to improve performance within the job for the benefit of the organization. The organization must work to develop and nurture engagement, which requires a two-way relationship between employer and employee." Engagement is about passion and commitment-the willingness to invest oneself and expand one's discretionary effort to help the employer succeed, which is beyond simple satisfaction with the employment arrangement or basic loyalty to the employer Blessing White (2008) Erickson (2005) Macey and Schnieder (2008)

\subsection{Benefits of an Engaged Employee}

Benefits are numerous, both to an organization and to the individual employee. In fact, employees involved in an Employee Engagement programs or tasks are bound to develop leading management skills as a result of their participation.

\subsubsection{Value added to the company}

The following are the benefits of an engaged employee to an organization.

- Refined employee capabilities in areas such as in areas such as team building, communication, analytical thinking, leadership, flexibility, conflict resolution and problem solving., retention thus manifesting obligation to corporate citizenship is surely a powerful factor in retaining staff.

- Reinforced productivity is acquired as employees return rejuvenated and stimulated.

- It enhances corporate gratification through demonstrating a commitment to viable development and organizations investing in the employee engagement projects also send a clear message that employee development is high on the organization's agenda.

- It identifies internal outstanding employees who can be a motivating force for change within the organization.

\subsubsection{Value added to an employee}

The following are the benefits of an engaged employee to an individual.

- Professional development is amplified by learning and applying new skills.

- It extends perspectives by coordinating with people from different nationalities, backgrounds and cultures and form lifelong bonds.

- One can be the one to lead the way and thus becoming the distinguished employee within your organization.

- The engaged employee becomes a part of the solution and thus enjoys the hands-on and dedicated experience. 
- An engaged employee is less likely to be fearful to challenge others and the organization to be their best.

- Engagement makes the employee effective agents in their own professional work and employees feel that they contribute to the economic value of their organizations.

\subsection{Drivers of Commitment and Engagement}

Towers Perrin carried out two sets of research, one in the US Towers Perrin Talent Report (2003) and one across six countries in Europe European Talent Survey (2004). They asked both groups questions on a variety of workplace factors in their Organization and practices, processes, culture, leadership style and development opportunities. In other words, all the key elements typically seen to be the drivers of workforce behavior. They found a top 10 list of drivers of attraction, engagement and retention. What they found was that while there were some similarities between the US and the European reports, the key factors were quite divergent in each list (Add table 2.1 here). Melcrum (2005) states that to fully embed employee engagement as a real business issue, requires commitment to building an integrated, multi-faceted strategy. In addition, a company built employee engagement strategy which takes into consideration company culture, leadership and other company facets improves the likelihood of success as opposed to off-the-shelf products or copying from other companies.

\subsection{Precedents of Commitment}

Productivity and retention rates generally fall further as employees become distracted, confused and preoccupied with potential outcomes immediately following an organizational transition such as a major restructuring, corporate downsizing, merger, acquisition, or even rapid growth spurt Cartwright and Cooper (1999) Bridges (1991). Furlonger (2005) covered the key dimensions that were considered in rating the Best Companies to work for survey that was compiled by Deloitte. These dimensions were ranked from most to least as follows:

1. Job Satisfaction.

2. Management Style.

3. Relationship and Trust.

4. Values and Culture.

5. Diversity.

6. Change and Transformation.

7. Leadership.

8. HR Policies and Procedures.

9. Training and Development.

10. Communication.

11. Rewards, Recognition and Performance Management. 
It is critical for the company to spell out the reasons for following the route of employee engagement. According to Towers Perrin (2003) research shows that companies with higher levels of employee engagement outperform their competitors in terms of profitability. They proceed to state that Managers must first understand what engages their employees and what factors drives engagement in their companies.

\subsubsection{Demographics}

A range of demographic variables have been found to be related to employee commitment (Mathieu and Zajac ,1990). For a variety of reasons, age has been found to be a positive predictor of employee commitment. As (Mathieu and Zajac, 1990) suggest, the older employees become, the less alternative employment options are available. As a result, older employees may view their current employment more favorably. In addition, Dunham et al (1994) suggest older employees may be more committed because they have a stronger investment and greater history with their organization. With regard to gender, a number of studies (Mathieu and Zajac, 1990) have reported women as being more committed than men. Marital status has also been shown to relate to commitment, with married employees usually showing more commitment (Mathieu and Zajac, 1990).

\subsubsection{Experienced anticipation}

This line of research suggests that employees will be more committed if there is a good match between what the person is looking for in a job, and what the job provides Dawis (1992). Premack and Wanous (1985) found a high positive correlation between realistic job previews and commitment.

\subsubsection{Recruitment procedures}

O’Malley (2000) suggests that organizations need to pay more attention to addressing employees' social need to affiliate and belong. He argues that employees want to be in environments that make them feel comfortable. Organizations have goals and values, and people recruited by the organization should share these. The argument here is that in order to create commitment, the organization must have the right sort of employees in the first instance. As (Parks and Floyd, 1996) point out, there are several things organizations can do to make employees feel welcomed and valued as the recruitment and selection process develops such as share details about the organization, provide employees with help and support throughout the recruitment and selection process and convey the interests and values that the organization shares with employees. Employers should, therefore, devote a portion of the selection process to assessing cultural fit.

\subsubsection{Induction and training}

Several studies have demonstrated a link between early job experiences and commitment Mignerey et al(1995). The induction program should be the ultimate step of the recruitment and selection process. A gratifying induction program will make current employees more familiar with and more at ease within the organization. Employees enter the organization with a presumption of compatibility and should be welcomed. This will make new recruits more 
likely to be perceptive to feedback and other interferences that encourage social alliance. (Gaertner and Nollen, 1989) found that commitment was related to employees' perceptions of organizational efforts to provide them with training, but not to their actual training experiences. IES research with numerous organizations also supports the relationship between the provision of training and development opportunities for staff and increased levels of commitment and job satisfaction.

\subsubsection{Correlation with managers and colleague}

The affiliation between managers and their employees reveals to the development of commitment. Several studies have found meaningful positive relationships between the two variables, that is, employees who have good relationships with their immediate managers have greater commitment Green et al. (1996) Nystrom (1990) Settoon et al (1996). Similarly, a recent study by the (CIPD, 2001) concluded that good relationships between managers and employees are one of the most important factors affecting motivation at work. Effective communication on job-related issues is a key ingredient in securing individual performance. To a great extent, individual line managers are responsible for ensuring that these maintenance behaviors occur. Indeed, managers are key to creating commitment in an organization, as was demonstrated in Barber et al (1999). With poor management, the most well developed organizational program can lead to failure at the point of transmission. As per to correlation with colleagues this relevant aspect, however, must not be neglected but maintained through frequent, pleasing contact with peers (Baumeister and Leary, 1995). Organizations that want to build high levels of commitment should look for ways to build this through group activities both in and out of work.

\subsubsection{Promotion}

Policies and practices concerning promotion can also affect commitment. For example, Schwarzwald et al (1992) found that commitment was higher among employees who had been promoted, and was also related to employees' perceptions that the organization had a preference of recruiting from their internal labor market. Among those who are considered for promotion, the outcome of the decision is likely to have an effect on commitment.

\subsubsection{Job satisfaction}

How happy an employee is in a job has profound effects on behavior and commitment. From meta-analyses (Iaffaldano and Muchinsky, 1985) it is clear that employees who enjoy their jobs will work harder and stay longer with their employers than employees who do not. In relation to commitment, job satisfaction and work-life satisfaction are very important. Job satisfaction is an enormous area; however, to be concise a satisfying job typically has three properties 1) It has intrinsically enjoyable features: (Mathieu and Zajac , 1990) found that the strongest correlation with commitment were obtained for job characteristics, particularly job scope (enrichment), 2) It provides an opportunity for growth and development, 3) It makes employees feel effective in their roles (that they can positively influence organizational outcomes. 


\subsubsection{Pay and reward}

According to (March and Simeon, 1958), real commitment often evolves into an exchange relationship in which individuals attach themselves to the organization in return for certain rewards or outcomes. Employees may remain with an organization because there are constraints against leaving and incentives for staying. It is important for organizations to structure the economics of the relationship in a way that will not obstruct commitment. Given monetary reward to employees in organizations is very important especially if the organization want to appreciate and achieve its goals and objectives. This is because monetary reward influences the commitment level of employees irrespective of their gender, work tenure and educational level. Therefore, inadequate monetary reward system is seen as a major disappointment of employees' commitment and this can bring about increase in absenteeism, lateness, low performance, feeling of grievances, and employees turnover.

\subsection{Maximizing Organizational Performance through Employee Commitment and Engagement}

Employee engagement is powerfully linked to a range of business success factors. Why should companies entrust in employee engagement? The answer is because employee engagement is associated significantly with important business outcomes. Studies have found positive relationship between employee commitment and engagement and organizational performance outcomes: employee retention, productivity, profitability, customer loyalty and safety. Researches also indicate that the more engaged employees are, the more likely their employer is to exceed the industry average in its revenue growth. Research also indicates that engagement is positively related to customer satisfaction Coffman (2000) Ellis and Sorensen (2007). Engaged employee consistently demonstrates three general behaviors which improve organizational performance.

- $\quad$ Say-the employee advocates for the organization to co-workers, and refers potential employees and customers.

- $\quad$ Stay-the employee has an intense desire to be a member of the organization despite opportunities to work elsewhere.

- $\quad$ Strive-the employee exerts extra time, effort and initiative to contribute to the success of the business (Baumruk and Gorman, 2006).

Financial News, March 2001, as cited by Accord Management Systems (2004), reveals that disengaged employees are more likely to cost their organization. According to the report, Employees who are disengaged.

- Miss an average of 3.5 more days per year.

- Are less productive.

- Cost the US economy $\$ 292$ to $\$ 355$ billion per year.

Engagement leads to higher financial performance, higher customer satisfaction and higher employee retention. It is important that the organization find ways to clearly communicate 
successes that demonstrate how the organization is performing, and especially to find ways to socialize stories of superior performance. Clear, suitable, high-impact messages can motivate employees not only see the association between their work and these successes, but also understand how they support overall organizational performance, which ties directly to engagement levels. Clearly, engaged employees understand the value of certifying a positive customer experience and are more likely to exhibit their commitment by delivering high quality products and services. Customer and employee-driven experiences that highlight great customer satisfaction and loyalty need to be effectively shared throughout the company. Like the connection to organizational performance, the connection to positive customer experiences is vital to healthy engagement levels. Engaged employees decrease functional costs because they demonstrate more commitment and achieve better than non-engaged employee. Therefore organizations need to conserve their assets in their workforce by retaining employees and their intellectual capital to assure business progression and the ability to meet key business objectives. Significance at work, advocacy for the organization, and organizational climate, these outcomes are products of a healthy workplace in which employees are engaged not only with their work, but also with their organization. This kind of engagement can lead to discretionary effort on the part of employees. Discretionary effort can be defined as "the extent to which employees put their full effort into their job, are constantly looking for ways to do their job better, are willing to put in the extra effort to get a job done when necessary, and believe that people would describe them as enthusiastic about the work they do" Corporate Leadership Council (2002) as cited in Equal Opportunities Trust (2007). According to EEO (2007), discretionary effort is an output of employee engagement. As well, "the greatest impact on discretionary effort comes from emotional commitment to one's job and the organization, i.e. engagement”. Employees who choose to exert extra effort and create positive outcomes for the organization are typically highly engaged with their workplaces.

\subsection{Creating a Committed and Engaged Workforce}

Employee commitment and engagement lifts improved organizational performance. So how do you formulate and sustain engagement in your workforce?

\subsubsection{Establish a unique collaborative culture}

Senior executives inclined to foresee about unique culture as a topic that's hard to measure and hard to alter. As a result, many choose not to invest in it in spite of all the evidence that, when skillfully managed, culture can be a powerful and enduring source of competitive advantage. Companies should advocate a strong work culture in which the goals and values of managers are build up across all work sections. Companies that build a culture of common respect by keeping success stories alive will not only keep their current employees engaged but also they regenerate the new incoming employees with this contagious spirit of work culture.

\subsubsection{Determine engagement zones}

The only way to accumulate precise information about employee engagement in your business is to measure it. Organizations require not only to comprehend their present level of employee engagement, but also to have assurance that the measures used to determine engagement are 
trustworthy and genuine. The most accurate way to achieve this is through a quantitative survey supported by qualitative interviews and focus groups. Surveys need to be adjusted to the organization, their plan of action and their values. By asking the right questions, the significant information can be uncovered, the performances and practices the organization needs to dispatch in the design of a solution.

\subsubsection{Leadership commitment}

Employee engagement requires leadership commitment through organizing clear mission, vision and values. Unless the people at the top trust in it, inherent it, pass it down to managers and employees, and improve their leadership, employee engagement will never be more than just a corporate conceit. This requires leaders to balance accountability with meaningful work to motivate employees into contributing to corporate success. Productive leadership can motivate employee engagement and coordinates to a demonstrated commitment to supporting the employees in their career progression. This involves ensuring employees contribute to corporate objectives they can identify with, and by giving meaningful employee recognition and development opportunities tailored to the individual.

\subsubsection{Elevate employee engagement through two-way communication}

Managers should promote two-way communication. Clear and persistent communication of what is expected of them paves the way for engaged workforce. Involve your people and always show respect to their input. Share power with your employees through participative decision making so that they would feel sense of belongingness thereby increasing their engagement in realizing it.

\subsubsection{Adjoin the execution to business outcomes}

Business leaders are required to correlate positive levels of employee engagement with lower turnover and absenteeism, higher productivity, and increased innovation. In doing so, these organizations build the business case for their leaders and employees to continue to support engagement objectives. This is acquired through developing and interpreting a collective database containing productivity data, customer data, HR data, and financial data for similar groups.

\subsubsection{Persist to track engagement levels}

Measuring engagement is not a onetime action. Organizations are constantly progressing and refining; therefore, organizations need to measure engagement and trace the prosperity of strategies the organization have undertaken to augment engagement and business effectiveness. Comprehensive surveys should be conducted across the organization annually or biannually, supported by shorter quarterly tracking surveys.

\subsubsection{Benchmark opponent methods}

Benchmarking is used to compare the organization's processes or products to other organizations, either internal or external to their own industry. Global, local and internal benchmarking can be conducted to. 
- Identify what is to be benchmarked.

- Identify competitive companies.

- Determine data collection method and collect data.

- Determine current performance levels.

- Project future performance levels.

- Communicate benchmark findings and gain acceptance.

- Establish functional goals.

- Develop action plans.

- Implement specific actions and monitor progress.

- Recalibrate benchmarks.

When used accordingly, benchmarking can be a great way to cultivate the team's performance and help the organization stay competitive. A carefully-designed assessment process is the key to getting the most out of your benchmarking effort.

\subsubsection{Engage and Retain top performers}

Excelling in creating a climate that will keep top performers engaged and employed at their organizations is the single most important priority for HR and talent executives right now. When top performers are fully engaged in their work and are coordinated with organizational goals, they are not only influential in stimulating a business, but also in helping to exemplify their organizations long-term expansion direction. Therefore managers need to be aware and adopt specific strategies to motivate and engage their top performers. Having a clearly coherent and enforced vision and set of values, and emphasizing these values to assure that top performers are both personally inspired and feel connected to a common purpose, ensuring that senior leaders share an understanding of the organization's vision and values and consistently model these values in their words and actions and seek the opinions of top performers on how to improve company competitiveness, and involve them in designing the programs or solutions required to address the issues they identify. Nierhoff et al (1990) found that the "overall management culture and style driven by the top management actions are strongly related to the degree of employee commitment”. Eisenberger et al (1990) discuss that those employee's who feel that they are cared for by their organization and managers also have not only higher levels of commitment, but that they are more conscious about their responsibilities, have greater involvement in the organization, and are more innovative. The employee commitment and engagement thus is the distinction between the employee's level of commitment and engagement has towards their job and career and level of commitment and engagement towards their organization.

\section{Discussion}

The literature study revealed significant factors that cater to the employee commitment and employee engagement towards their organization. Relationship and trust, values and culture, effective leadership, HR policies and procedures, training and development, pay satisfaction, , 
autonomy and satisfaction with supervision are all positively related to the effective and responsible commitment of employees towards the organization and its success. The study makes a contribution to the literature by examining the relationship of individual level values that is required to have a connection with the organizational values. So far we have discussed the evolution and definition of employee engagement, the factors that affect it and importance of employee engagement explaining how it is linked to business performance. Now, at this stage the employee engagement strategies that most of the recent companies are adapting and are visioning is what management of most of the entities needs to look and implement to create engagement from disengaged employee.

"Creating an engaging workplace is core to our business success. It is critical that our staff is engaged in what we do as our customers have a constant view of our staff at work. Winning the Achievers 50 Most Engaged Workplaces ${ }^{\mathrm{TM}}$ Award was a huge boost not just to RocketSpace staff but to all the companies we house. It reminded us that we are all fundamentally people businesses dependent on the performance of our teams.” D. Logan (2012). "One of All Weather Windows' core values is to be a Diverse and Engaged Team and we know that an engaged and dedicated workforce is essential to delivering on our promise to relentlessly pursue customer satisfaction, one customer at a time. Being named one of the Achievers 50 Most Engaged Workplaces ${ }^{\mathrm{TM}}$ is a testament to our commitment to employee engagement and shows that we live our values. The Award demonstrates to potential employees that All Weather Windows is a truly outstanding place to work and we are certain it will encourage people to join our team.” P. Taylor (2012). It has become evident that employees want leaders of organizations to create a workplace environment that engages each employee regardless of age, location or personality. Organizations who believe that their employees are their number one asset are able to achieve long lasting vendor and client relations because they would like to do business with organizations who have similar values, awards like achievers 50 most engaged workplace is due to the recognition the commitment to employee engagement which involves the whole organizations contributions to engaged workplace and top talent who is looking for a job look for organization where they are fully appreciated and encouraged to achieve their best.

Given the economic volatility employee engagement becomes more critical than in normal conditions. Aspiring to maintain a higher level of employee engagement not only contributes toward short-term survival during economic volatility, but is also a key factor for longer-term business attainment and better positioning when market conditions become favorable. The companies that get engagement "right" will enjoy a source of competitive advantage in talent strategy and business results that is hard for others to duplicate.

Recommended top opportunities to improve and maintain employee engagement are career opportunities, recognition, and organization reputation. It is explained as below why each driver has positive impact to overall engagement levels.

Career opportunities are directly connected to employee's career path within an organization. It is extremely significant to remember that the manager is responsible of this critical engagement 
driver therefore managers strong and relevant leadership plays an important role to communicate a clear career path for their teams and prepare them for the next role level.

Recognition comes at no cost to the organization therefore positive reinforcement is critical to the motivation and the engagement equation. As the organizations mange cost and growth pressure during tough times their recognition towards their employees during the rough business climate will pay the organization long term dividends.

Employees also get engaged with a notion that they are working for the best employer in the region. The psychology of a professional is to be a part of a wining team. Therefore the role of the employers with this significant engagement driver is for the organization to be religiously connected to the organizations mission, successful business performance and a package of value proposition which is asset of rewards and a work experience which cannot be replicated anywhere.

What should employees engage in? This is a valid question to assess how to manage performance and to focus on individual objectives that enable true employee effectiveness. Organizations may score high on employee engagement but if performance management score is low than they are required to ask "are employees engaged in the right behaviors". Organizations that apply employee centric avenue will win. In solving the employee commitment and engagement equation the valid statement to be asked is "What do employees need in order to be engaged?”

\section{Conclusion}

The literatures indicate that employee commitment and engagement are closely linked with organizational performance outcomes. Engaged employees directs to magnified productivity, retention, consumer loyalty and profitability. Organizations who know whether employees are engaged to both the jobs that they do and the company that they work for accredit organizations to forecast behavior and its impact on key business metrics. Assessment without action can do more damage than good. Plainly surveying for the current engagement level and then doing nothing with that information often leads to employees perceiving that they aren't being attended, which in turn can negatively impact confidence and trust levels. Recognizing and analyzing engagement levels and the drivers of success is the first step. The real question is in supplying your organization and business to perform and safeguard that transition is implanted in your working culture so that your workforce remains focused and aligned to the organizational and business strategy and goals. Organizations that take positive steps to construct commitment appreciate that it is a vital component of business success. Commitment is a two way process which the organization itself has to commence. Engagement strategies cannot be shallow level; in order to be effective, they must become a part of the organizational culture. When employee and organization goals are regulated, employees are more likely to be engaged with their work and it is possible to promote pragmatic, achievable goals that foster productivity. Employees that are engaged strive discretionary effort at work, creating extra value for the organization. A culture of employee commitment and engagement leads to a culture of performance. 


\section{References}

Accord Management Systems. (2004). Employee Engagement Strategy: A Strategy of Analysis to Move from Employee Satisfaction to Engagement. Retrieved June 12, 2012, from Accord Management System Website: www.accordsyst.com/papers/engagement_wp.pdf

Balfour, D., \& Wechsler, B. (1996).Organizational commitment: Antecedents and outcomes in public organizations. Public Productivity and Management Review, 29, 256-277. http://dx.doi.org/10.2307/3380574

Barber, L., Hayday, S., \& Bevan, S. (1999). From people to profits, IES Report 355. Retrieved October 19 from Institute of Employment studies website http://www.employment-studies.co.uk/pubs/summary.php?id=355

Baumeister, R., \& Leary,M. (1995).The need to belong: Desire for interpersonal attachments as a fundamental human motivation Psychological Bulletin, 117, 497-529. http://dx.doi.org/10.1037//0033-2909.117.3.497

Baumruk R., \& Gorman, B. (2006). Why managers are crucial to increasing engagement. Retrieved June 17, 2012, from Melcrum Publishing Inc Website: http://www.insala.com/employee-engagement/why-managers-are-crucial-to-increasingengage ment.pdf.

Blessing White. (2008). The Employee Engagement Equation in India. Presented by Blessing White and HR Anexi. Retrieved June 12, 2012, from Blessing White Website: www.blessingwhite.com

Bridges, William. (1991). Managing transitions-Making the most of change. Cambridge, MA: Perseus Books. Retrieved from http://www.questia.com/PM.qst?a=o\&d=99472981

Brown, R.B. (1996). Organizational commitment: clarifying the concept and simplifying the existing construct typology. Journal of Vocational Behavior, 49, 230-251. http://dx.doi.org/10.1006/jvbe.1996.0042

Coffman, C. (2000). Is Your Company Bleeding Talent? How to become a true "employer of choice”. The Gallup Management Journal. Retrieved July 1, 2012, from the Gallup Organization Website: http://businessjournal.gallup.com/content/292/your-companybleeding-talent.aspx

Cohen ,A. (1991). Career stage as a moderator of the relationship between organizational commitment and its outcomes: A meta- analysis'. Journal of Occupational Psychology, 64, 253-268. http://dx.doi.org/10.1111/j.2044-8325.1991.tb00558.x

Cohen, A. (1993). Age and tenure in relation to organizational commitment: A meta-analysis.

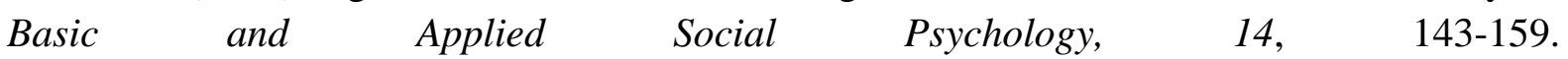
http://dx.doi.org/10.1207/s15324834basp1402_2

Dawis, R. V. (1992). Person-environment fit and job satisfaction.In C. J. Cranny, P. C. Smith, \& E. F. Stone (Eds.), Job satisfaction. New York: Lexington 
Dernovsek ,D. (2008). Creating highly engaged and committed employee starts at the top and ends at the bottom line Credit Union Magazine, May 2008. Credit Union National Association, Inc.

Dunham, R., Grube, J., \& Castaneda , M. (1994). Organizational Commitment: The utility of an integrative definition. Journal of Applied Psychology, 79, 370-380. http://dx.doi.org/10.1037/0021-9010.79.3.370

Eisenberger, R., Fasolo, P., \& Davis, LaMastro. Perceived Organizational Support and Employee Diligence, Commitment and Innovation. Journal of Applied Psychology, 75(1), 5159.

Ellis, C. M., \& Sorensen, A. (2007). Assessing Employee Engagement: The Key to Improving Productivity. Perspectives, Vol.15, Issue 1 The Segal Group, Inc. Retrieved on October 19, 2012, from http://www.sibson.com/uploads/32629d167f83f7f521992723c4c9f100.pdf

Equal Employment Opportunities Trust. (2007). Work-life balance, employee engagement and discretionary effort: A review of the evidence. New Zealand: McPherson, Mervyl. Retrieved July 2, 2012, from http://www.eeotrust.org.nz/content/docs/reports/Workllife\%2C\%20employee\%20engagemen t\%20report\%20-\%20Survey.doc

Erickson, T. J. (2005). Testimony submitted before the US Senate Committee on Health, Education, Labour and Pensions. May 26.

Furlonger, D. (2005). Best of the Best, Financial Mail, 30, 20.

Gaertner, K., \& Nollen S. (1989). Career experiences, perceptions of employment practices, and psychological commitment to the organization. Human Relations, 42, 975-991. http://dx.doi.org/10.1177/001872678904201102

Green, S., Anderson S., \& Shivers, S. (1996). Demographics and organizational influences on leader member exchange and related work attitudes. Organizational Behavior and Human Decision Processes, 66, 203-214. http://dx.doi.org/10.1006/obhd.1996.0049

Iaffaldano, M., \& Muchinsky P. (1985). Job satisfaction and job performance: A meta analysis. Psychological Bulletin, 97, 251-273. http://dx.doi.org/10.1037/0033-2909.97.2.251

Katz, D. (1964). The motivational basis of organizational Behavior. Behavioral Science, 9, 131-146. http://dx.doi.org/10.1002/bs.3830090206

Logan, D. (2012). 50 Most Engaged workplaces. Retrieved October 20, 2012, from Achievers website: http://www.achievers.com/engaged/why-apply.php

Macey, W.H., \& Schneider, B. (2008). The Meaning of Employee Engagement. Industrial and Organizational Psychology, 1, 3-30. http://dx.doi.org/10.1111/j.1754-9434.2007.0002.x 
Mathieu, J., \& Zajac D. (1990).A review and meta-analysis of the antecedents, correlates, and consequences of organizational commitment. Psychological Bulletin, 108, 171194. http://dx.doi.org/10.1037/0033-2909.108.2.171

March, J., \& Simeon, W. (1958). Organization behavior. New York: McGraw-Hill, 43-68

Melcrum Publishing. (2005). an Independent Research Report on Employee Engagement: How to build a high -performance workforce. Retrieved July 1, 2012, from Melcrum Publishing Inc Website: http://www.melcrum.com/offer/ee/_pdf/engagementsummary07d.pdf

Mignerey, J., Rubin R., \& Gordon W. (1995). Organizational entry: An Investigation of newcomer communication behavior and uncertainty. Communication Research, 22, 54-85. http://dx.doi.org/10.1177/009365095022001003

Niehoff, B.P., Enz, C.A., \& Grover, R.A. (1990). The impact of top-management actions on employee attitudes and perceptions. Group \& Organization Studies, 15(3), 337- 352. http://dx.doi.org/10.1177/105960119001500307

Nystrom, P. (1990).Vertical exchanges and organizational commitments of American business managers. Group and Organizational Studies, 15, 296-312. http://dx.doi.org/10.1177/105960119001500305

O’Malley, M. (2000). Creating commitment. John Wiley \& Sons. Chichester

O’Reilly III, C., \& Chatman, J. (1986). Organizational commitment and psychological attachment: The effects of compliance, identification, and internalization on prosocial behavior. Journal of Applied Psychology, 71(3), 492-499. http://dx.doi.org/10.1037/0021-9010.71.3.492

Parks M., \& Floyd K. (1996). Meanings for closeness and intimacy in friendship. Journal of Social and Personal Relationships, 13, 85-107. http://dx.doi.org/10.1177/0265407596131005

Perrin, T. (2003). Working Today: Understanding What Drives Employee Engagement. The 2003 Towers Perrin Talent Report U.S Report. Retrieved June 28, 2012 from Website: http://www.towersperrin.com/tp/getwebcachedoc?Webc=HRS/USA/2003/200309/Talent_20 03.pdf (October 30, 2008)

Porter, L.W., Steers, R.M., Mowday, R.T., \& Boulian, P.V. (1974). Organizational commitment, job satisfaction, and turnover among psychiatric technicians. Journal of Applied Psychology, 59, 603-609. http://dx.doi.org/10.1037/h0037335

Premack, S., \& Wanous J. (1985).A meta-analysis of realistic job preview experiments. Journal of Applied Psychology, 70, 706-719. http://dx.doi.org/10.1037/0021-9010.70.4.706

Robinson, D., Perryman S., \& Hayday, S. (2004). The Drivers of Employee Engagement Report 408, Institute for Employment Studies, UK

Settoon R., Bennet N., \& Liden R. (1996). Social exchange in organizations: Perceived organizational support, leader member exchange, and employee reciprocity. Journal of Applied Psychology, 81, 219-227. http://dx.doi.org/10.1037/0021-9010.81.3.219 
Scholl, R. W. (1981). Differentiating organizational commitment from expectancy as a motivating force. Academy of Management Review, 6: 589-599.

Schwarzwald, J. Koslowsky M., \& Shalit B. (1992).A field study of employees’ attitudes and behaviors after promotion decisions. Journal of Applied Psychology, 77, 511514. http://dx.doi.org/10.1037/0021-9010.77.4.511

Taylor, P. ( 2012). 50 Most Engaged workplaces. Retrieved October 20, 2012, from Achievers website: http://www.achievers.com/engaged/why-apply.php

Towers Perrin. (2003). the Towers Perrin Talent Report. Working Today: Understands what drives Employee Engagement. Retrieved June 28, 2012 from Towers Perrin Website: http://www.towersperrin.com/tp/getwebcachedoc?webc=hrs/usa/2003/200309/talent_203.pdf

Towers Perrin. (2003). Tougher Times. Tougher HR. September pp. 17-37.

Vandenberg, R., \& Lance C. (1992).Satisfaction and organizational commitment. Journal of Management, 18, 153-167. http://dx.doi.org/10.1177/014920639201800110

Table 2.1. Comparison of drivers in Europe vs. US \& Towers Perrin (2003).

\begin{tabular}{|c|c|c|c|}
\hline \multicolumn{2}{|r|}{$\begin{array}{c}\text { Top } 10 \text { Attraction } \\
\text { Drivers }\end{array}$} & $\begin{array}{c}\text { Top } 10 \text { Engagement } \\
\text { Drivers }\end{array}$ & Top 10 Retention Drivers \\
\hline 1. & Work/life balance & $\begin{array}{l}\text { Senior management interest } \\
\text { in employees }\end{array}$ & $\begin{array}{l}\text { Manager inspires enthusiasm for } \\
\text { work }\end{array}$ \\
\hline 2. & Recognition for work & Ability to improve skills & $\begin{array}{l}\text { Career advancement } \\
\text { opportunities }\end{array}$ \\
\hline 3. & Career Advancement opportunities & $\begin{array}{l}\text { Senior management } \\
\text { demonstrates values }\end{array}$ & $\begin{array}{l}\text { Company reputation as a good } \\
\text { employer }\end{array}$ \\
\hline 4. & Challenging work & Challenging work & $\begin{array}{l}\text { Fair and consistent pay } \\
\text { determination }\end{array}$ \\
\hline 5. & Competitive Pay & Decision - making authority & $\begin{array}{l}\text { Intent to work after retirement in } \\
\text { another field }\end{array}$ \\
\hline 6. & Learning/Development opportunities & $\begin{array}{l}\text { Company reputation as a } \\
\text { good employer }\end{array}$ & Decision making authority \\
\hline 7. & Job autonomy & $\begin{array}{l}\text { Ability to influence company } \\
\text { decisions }\end{array}$ & Overall work environment \\
\hline 8. & Variety of work & $\begin{array}{l}\text { Company focus on customer } \\
\text { satisfaction }\end{array}$ & $\begin{array}{l}\text { Intent to work after retirement to } \\
\text { stay active }\end{array}$ \\
\hline 9. & Pay rises linked to individual performance & $\begin{array}{l}\text { Fair and consistent pay } \\
\text { determination }\end{array}$ & $\begin{array}{l}\text { Manager provides access to } \\
\text { learning } \\
\text { opportunities }\end{array}$ \\
\hline 10. & Company reputation as a good employer & Overall work environment & $\begin{array}{l}\text { Senior management } \\
\text { demonstrates values }\end{array}$ \\
\hline
\end{tabular}




\section{Macrothink}

Journal of Management Research

ISSN 1941-899X

2013, Vol. 5, No. 1

Table 2.2. The Top 10 Drivers in the US

\begin{tabular}{|c|c|c|c|}
\hline \multicolumn{2}{|r|}{$\begin{array}{c}\text { Top } 10 \text { Attraction } \\
\text { Drivers }\end{array}$} & $\begin{array}{c}\text { Top } 10 \text { Engagement } \\
\text { Drivers }\end{array}$ & Top 10 Retention Drivers \\
\hline 1. & Competitive Healthcare benefits & $\begin{array}{l}\text { Senior management interest in } \\
\text { employees }\end{array}$ & $\begin{array}{l}\text { Career advancement } \\
\text { opportunities }\end{array}$ \\
\hline 2. & Competitive Pay & Challenging work & Retention of high-caliber people \\
\hline 3. & Work/life balance & Decision - making authority & Overall work environment \\
\hline 4. & Competitive retirement benefits & $\begin{array}{l}\text { Company focus on customer } \\
\text { satisfaction }\end{array}$ & Ability to improve skills \\
\hline 5. & Career Advancement opportunities & Career Advancement opportunities & Resources to get job done \\
\hline 6. & Challenging work & $\begin{array}{l}\text { Company reputation as a good } \\
\text { employer }\end{array}$ & Competitive Pay \\
\hline 7. & Caliber of coworkers & Collaboration with coworkers & Clear goals from manager \\
\hline 8. & $\begin{array}{l}\text { Pay rises linked to individual } \\
\text { performance }\end{array}$ & Resources to get job done & Challenging work \\
\hline 9. & Recognition for work & $\begin{array}{l}\text { Ability to influence company } \\
\text { decisions }\end{array}$ & $\begin{array}{l}\text { Manager inspires enthusiasm for } \\
\text { work }\end{array}$ \\
\hline 10. & $\begin{array}{l}\text { Company reputation as a good } \\
\text { employer }\end{array}$ & Senior management vision & Overall satisfaction with benefits \\
\hline
\end{tabular}

